\title{
Klippel Treunanay Syndrome in differential diagnosis of cerebral palsy
}

\section{Serebral palsi ayırıcı tanısında Klippel Treunanay Sendromu}

\author{
Pakize KARAOĞLU ${ }^{1}$, Yasemin TOPÇU ${ }^{2}$, Erhan BAYRAM ${ }^{3}$, Uluç YİŞ ${ }^{1}$, Handan GÜLERYÜZ ${ }^{4}$, Semra HIZ $^{1}$ \\ ${ }^{1}$ Dokuz Eylül Üniversitesi Tıp Fakültesi, Çocuk Nöroloji Bilim Dalı, İzmir \\ ${ }^{2}$ Kanuni Sultan Süleyman Ĕ̆itim ve Araştırma Hastanesi, Çocuk Nöroloji Kliniği, İstanbul \\ ${ }^{3}$ Bolu İzet Baysal Devlet Hastanesi, Çocuk Nöroloji Kliniği i, Bolu \\ ${ }^{4}$ Dokuz Eylül Üniversitesi Tıp Fakültesi, Radyoloji Anabilim Dalı, İzmir
}

\begin{abstract}
Klippel Treunanay Syndrome is a rare disorder characterised by congenital vascular malformations and hypertrophy of soft tissues and bones. Here we report a 5-yearold child who was referred to our department of pediatric neurology with an initial diagnosis of cerebral palsy because of difficulty in walking and unilateral atrophy of his extremities. Detailed physical examination revealed left hemihypertrophy and port-wine stain. With these findings and venous malformations of the brain he had a final diagnosis of Klippel Treunanay Syndrome. While investigating cerebral palsy (CP) in children experiencing difficulty in walking, a detailed physical examination should be performed and accompanying unilateral hypertrophy and skin findings should suggest the presence of Klippel Treunanay Syndrome.
\end{abstract}

Key words: Cerebral palsy, children, Klippel Treunanay Syndrome

ÖZET

Klippel Treunanay sendromu konjenital vasküler malformasyonlar, kemik ve yumuşak doku hipertrofisi ile karakterize ender bir hastalıktır. Burada çocuk nöroloji kliniğimize yürüme güçlüğ̈̈ ve tek taraflı ekstremite atrofisi nedeniyle, serebral palsi ön tanısı ile gönderilmiş, 5 yaşında bir olgu sunulmuştur. Daha dikkatli bir fizik inceleme ile sol taraflı hemihipertrofisi ve porto şarabı lekesi olduğu görülen ve beyinde venöz malformasyonları saptanan olgu Klippel Treunanay sendromu tanısı almıştır. Yürüme güçlüğü ile başvuran olgular serebral palsi açısından değerlendirilirken fizik inceleme ayrıntılı olarak yapılmalı, eşlik eden tek taraflı hipertrofi ve deri bulguları varlığında Klippel Treunanay sendromu akla gelmelidir.

Anahtar kelimeler: Çocuk, Klippel Treunanay sendromu, serebral palsi

Alındığı tarih: 16.09 .2014
Kabul tarihi: 07.01 .2015

Yazışma adresi: Uzm. Dr. Pakize Karaoğlu, Dokuz Eylül Üniversitesi Tıp Fakültesi, Nevvar Salih İşören Çocuk Hastanesi, Çocuk Nöroloji Bilim Dalı, İnciralt1-35340-İzmir

e-mail: pakizekaraoglu@gmail.com

\section{INTRODUCTION}

Klippel Treunanay Syndrome (KTS) consists of two major features; congenital vascular malformations and disturbed growth. For diagnosis presence of either capillary or venous malformations with disturbed growth of the bone or soft tissues (in length or girth) is required ${ }^{(1)}$. Vascular malformations are mostly located on the skin and called vascular birthmarks. They usually develop during the neonatal period and grow with the child ${ }^{(2)}$. A capillary malformation "port-wine stain" consists of extended capillary vessels in the superficial dermis of the skin ${ }^{(3)}$. Venous malformations are most frequently seen anomalies of the deep venous system. It is thought to be due to a mesodermal abnormality during early fetal development and its management is conservative ${ }^{(1,4)}$. Here we report a case of KTS who was referred with an initial diagnosis of cerebral palsy (CP) since he had discrepancy between the sizes of 
his extremities and difficulty while walking. With normal neurologic examination and additional vascular lesions he was diagnosed as KTS.

\section{CASE REPORT}

A-5 year old male was admitted to our department of pediatric neurology because of limping while walking. He had been followed up with the diagnosis of $\mathrm{CP}$ since he started limping while walking and
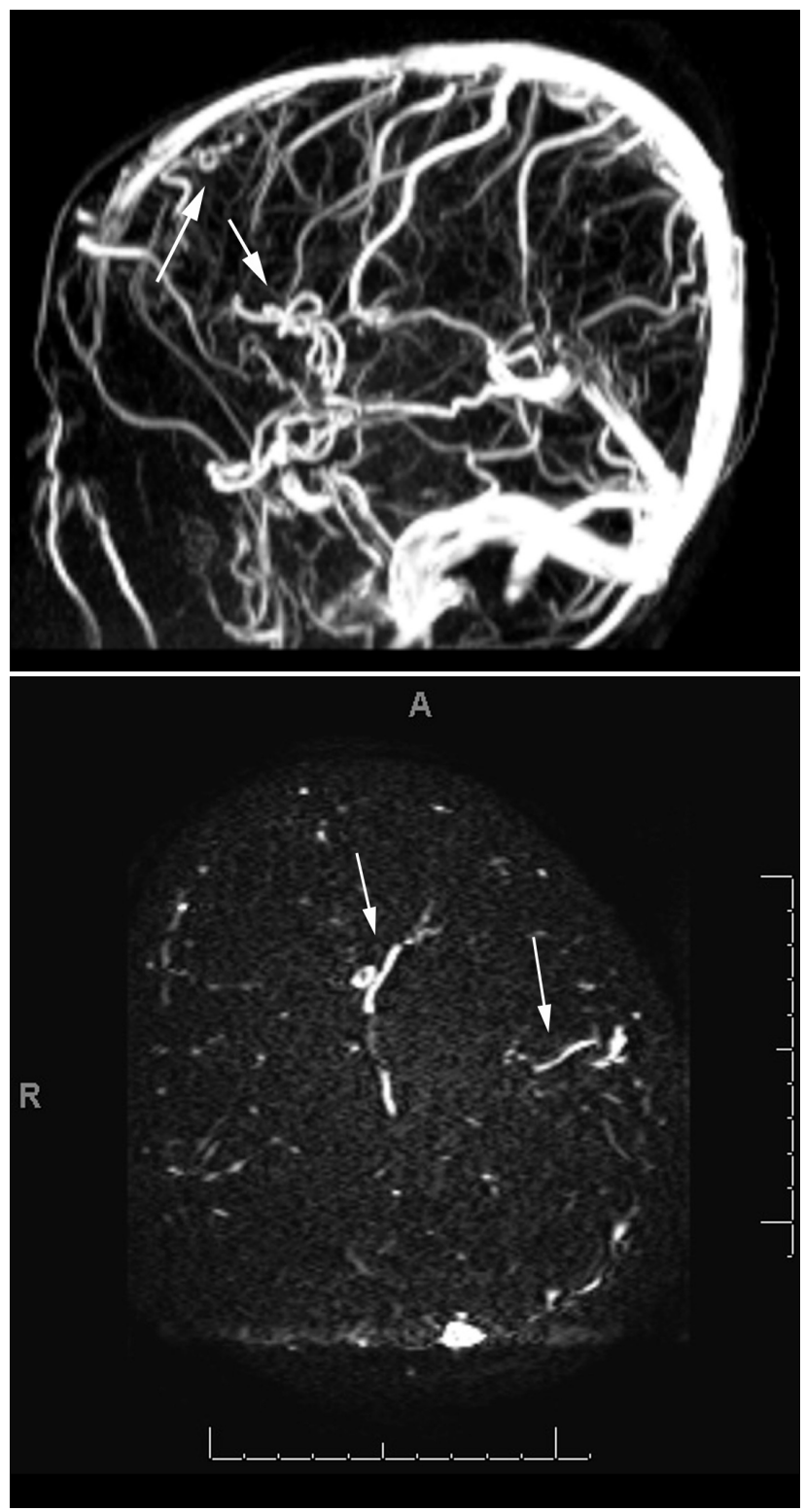

Figure 1. Cerebral MR venography image (a) shows venous abnormalities (arrows). Transverse raw image (b) shows frontal and parietal located venous malformations (arrows). thinning of the extremities on the right side of his body was observed. He was referred to our department for further evaluation of CP. His perinatal and natal period was uneventful. However, after birth he had been hospitalized because of skin lesions resembling cutis marmaratus. He was evaluated for the symptoms and signs of sepsis but physical examination besides the skin findings and all the laboratory
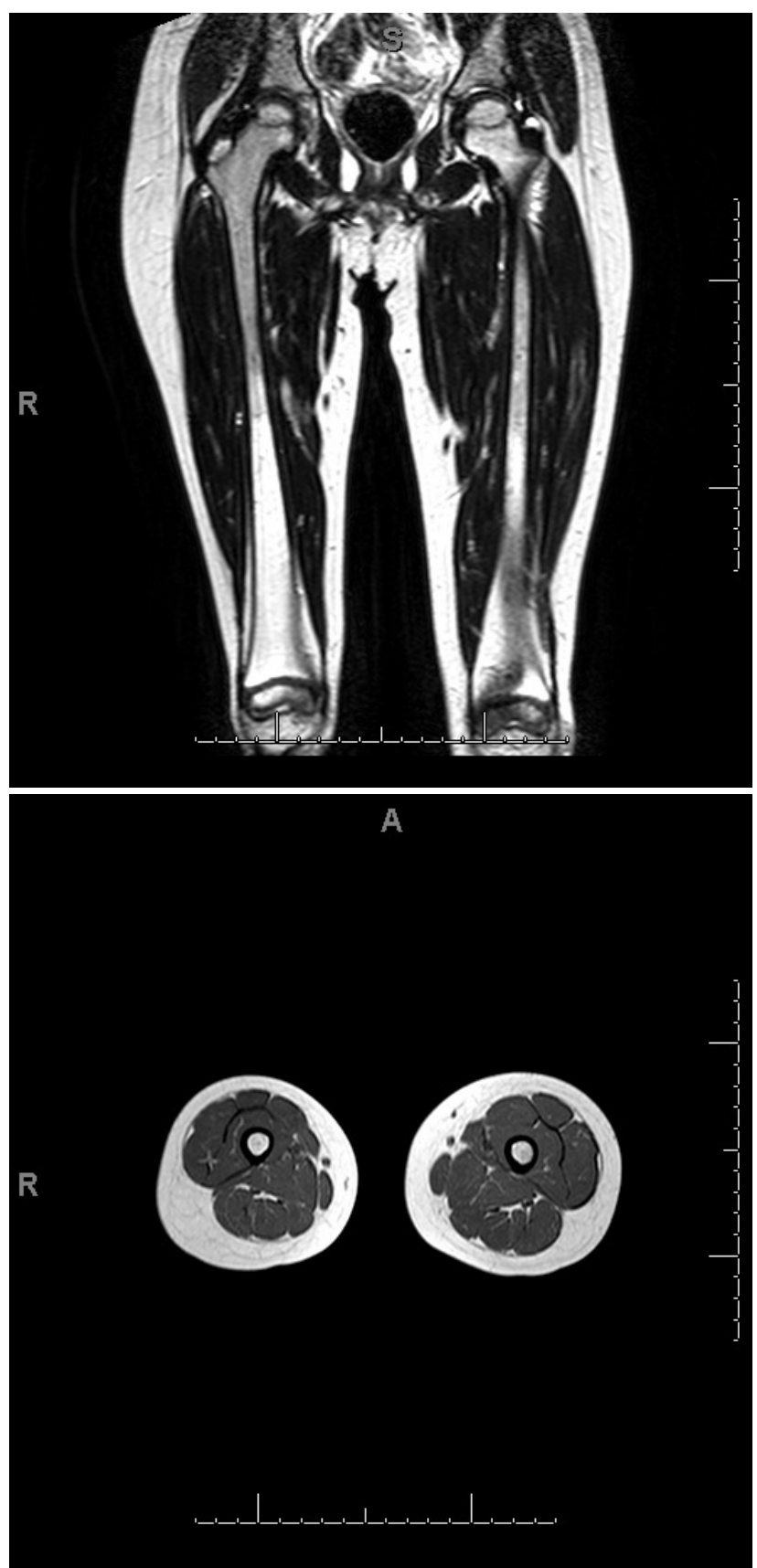

Figure 2. Lower extremity MR coronal (a) and transverse (b) images demonstrate asymetric left leg hypertrophy. 
examinations were within normal limitsl. Then the skin findings were evaluated as "vascular birthmarks". His developmental milestones were normal for his age. On physical examination, hypertrophy of the left upper and lower extremities with widespread port- wine stain on his face, lower lip, arms, legs and trunk were noted. Cranial nerves were intact. His muscle strength was normal with normoactive deep tendon reflexes. Pathological reflexes were absent. Cerebellar tests were normal. Brain magnetic resonance imaging (MRI) revealed prominent vascular structures located periventricularly and adjacent to the corpus callosum. These structures were thought to be vascular malformations. On brain magnetic resonance angiography (MRA) ectatic, varicose deep veins (venous malformations) were detected (Figure 1). His lower extremity MRI showed hypertrophy of bones and soft tissues on the left side without any vascular malformation (Figure 2). Ophtalmologic examination was normal. Arterial, and venous Doppler ultrasonographic examinations of the upper and lower extremitie did not reveal any vascular malformation. As the child has capillary malformations (port wine stains), soft tissue and bone hypertrophy and venous vascular malformations on deep veins of the brain, a diagnosis of KTS was made.

\section{DISCUSSION}

Cerebral palsy is the sequence of damage of the brain before, during or after the birth. In hemiparetic $\mathrm{CP}$ power reduction of the spastic muscles and atrophy of the hemiparetic body half occurs ${ }^{(5)}$. Also volume loss of the spastic musculature is seen ${ }^{(5)}$. These can give rise to gait disturbances. Our case was initially evaluated as CP since he had thinning of the right upper and lower extremities and limping while walking. On the other hand, his medical history revealed uneventful perinatal, natal and postnatal periods. Vascular lesions present since birth and left sided hemihypertrophy with normal muscle strength and reflexes were suspected to be a part of a syndromic disease. Capillary malformations (port-wine stains), venous malformations of the brain and left sided bone and soft tissue hypertrophy led us to the diagnosis of KTS.

KTS is described as a clinical triad of (1); capillary malformations (port- wine stain) (2); soft tissue or bone hypertropy or hypotrophy and (3); mostly lateral varicosity ${ }^{(4)}$. It is also reported that the clinical presentation can be variable and varicosities do not need to be present ${ }^{(1)}$.

KTS consists of two major features; congenital vascular malformations and disturbed growth. Congenital vascular malformations can be capillary, venous, arteriovenous or lymphatic malformations. For diagnosis, presence of either capillary or venous malformations with disturbed growth of the bone or soft tissues (in length or girth) is required ${ }^{(1)}$. Vascular malformations are mostly located on the skin and called vascular birthmarks. They usually develop during the neonatal period as in our patient and grow with the child ${ }^{(2)}$. Capillary malformations are the most common cutaneous manifestations of KTS. A capillary malformation "port-wine stain" consists of extended capillary vessels in the superficial dermis of the skin ${ }^{(3)}$. Venous malformations are most frequently anomalies of the deep venous system. They occur most frequently in the legs but can be seen anywhere (6). Central nervous system can be involved through hemimegaencephaly, aneurysms and vascular malformations ${ }^{(7)}$. KTS is thought to be due to a mesodermal abnormality during early stage of the fetal development ${ }^{(1)}$. Most cases of KTS arise from sporadic mutations in one or more genes involved in the early embryonic angiogenesis such as $\mathrm{AGGF}^{(1,7)}$. Frequent complications of KTS related to the anomalous veins include symptomatic venous engorgement, superficial thrombophlebitis, venous thrombosis and pulmonary thromboembolism ${ }^{(8)}$. Opthalmologic findings such as unilateral mature cataract and vitreoretinopathy are reported in the literature and ophthalmic examination is necessary in patients with KTS ${ }^{(9)}$.

KTS should be differentiated from Parkes-Weber Syndrome which is characterised by a high flow arteriovenous malformation together with limb hypertro- 
phy and capillary malformations ${ }^{(4)}$. Port-wine nevus is a feature of Sturge-Weber Syndrome and it is associated with glaucoma, seizures, paresis and neurodevelopmental delay. Neuroradiological findings of this syndrome are leptomeningeal enhancement with cortical atrophy and calcifications ${ }^{(10)}$.

Presentation of our case was different since he was referred to us with a diagnosis of CP. When a child is limping during walking and discrepancies in length or girth of extremities are detected, a detailed and careful neurologic examination should be performed. Differences in muscle strength and deep tendon reflexes with the presence of pathologic reflexes can raise the suspicion of $\mathrm{CP}$. However if neurologic examination is normal, the discrepancy might be due to hypertophy of one side of the body and presence of vascular malformations should be investigated for KTS.

\section{REFERENCES}

1. Oduber CE, van der Horst CM, Hennekam RC. KippelTrenaunay syndrome: diagnostic criteria and hypothesis on etiology. Ann Plast Surg 2008;60(2):217-223. http://dx.doi.org/10.1097/SAP.0b013e318062abc1
2. Mulliken JB, Glowacki J. Hemangiomas and vascular malformations in infants and children: a classification based on endothelial characteristics. Plast Reconstr Surg 1982;69:412-422. http://dx.doi.org/10.1097/00006534-198203000-00002

3. Baskerville PA, Ackroyd JS, Lea Thomas M. The KlippelTrenaunay syndrome: clinical, radiological and haemodynamic features and management. Br J Surg 1985;72:232-236. http://dx.doi.org/10.1002/bjs.1800720331

4. Gloviczki P, Driscoll DJ. Klippel-Trenaunay syndrome: current management. Phlebology 2007;22(6):291-298. http://dx.doi.org/10.1258/026835507782655209

5. Lampe R, Grassl S, Mitternacht J, et al. MRT-measurements of muscle volumes of the lower extremities of youths with spastic hemiplegia caused by cerebral palsy. Brain Dev 2006;28(8):500-506. http://dx.doi.org/10.1016/j.braindev.2006.02.009

6. Young AE. Venous and arterial malformations. In: Mulliken JB, Young AE, eds. Vascular Birthmarks: Hemangiomas and Malformations. Philadelphia:W. B. Saunders Company 1988:196-214.

7. Ricks CB, Grandhi R, Ducruet AF. Klippel-Trenaunay syndrome and cavernous malformations. BMJ Case Rep 7; 2014 http://dx.doi.org/10.1136/bcr-2014-207486

8. Uller W, Fishman SJ, Alomari AI. Overgrowth syndromes with complex vascular anomalies. Semin Pediatr Surg 2014;23(4):208-215. http://dx.doi.org/10.1053/j.sempedsurg.2014.06.013

9. Olcaysu OO, Altun A, Olcaysu E, Marzıoğlu Ozdemır E, Demir B. Unilateral cataract and vitreoretinopathy in a case with klippel-trenaunay syndrome. Case Rep Ophthalmol Med 2014;2014:312030. http://dx.doi.org/10.1155/2014/312030

10. Chhajed M, Pandit S, Dhawan N, Jain A. Klippel-Trenaunay and Sturge-Weber overlap syndrome with phakomatosis pigmentovascularis. J Pediatr Neurosci 2010;5(2):138-140. http://dx.doi.org/10.4103/1817-1745.76113 